Portland State University

PDXScholar

$5-22-2020$

\title{
Pregnancy and the Apocalypse: the Enlistment of Reproductive Futurism in Aid of Nationalism
}

\author{
Emily E. Horger \\ Portland State University
}

Follow this and additional works at: https://pdxscholar.library.pdx.edu/honorstheses

Part of the Film and Media Studies Commons, and the Political Science Commons Let us know how access to this document benefits you.

\section{Recommended Citation}

Horger, Emily E., "Pregnancy and the Apocalypse: the Enlistment of Reproductive Futurism in Aid of Nationalism" (2020). University Honors Theses. Paper 920.

https://doi.org/10.15760/honors.942

This Thesis is brought to you for free and open access. It has been accepted for inclusion in University Honors Theses by an authorized administrator of PDXScholar. Please contact us if we can make this document more accessible: pdxscholar@pdx.edu. 
Pregnancy and the Apocalypse:

The Enlistment of Reproductive Futurism in Aid of Nationalism

by

Emily Horger

An undergraduate honors thesis submitted in

partial fulfillment of the requirements for the degree of

Bachelor of Science

in

University Honors

and

Arts and Letters

Thesis Advisor

Kathi Inman Berens, Ph.D.

Portland State University

2020 
The embodiment of power is, at times, a physical embodiment. How often has it been said that the future must be protected for the sake of our children, for our children's children? The future is a world of infinite possibility and chaos, and those who can exert influence on the formation of the future are those who hold power over the present. Foucault's The Birth of Biopolitics and other works describe the idea that states gain and maintain power largely through control over life and the reproduction of life. In recent news from around the world we can see the truth of this idea, as individuals are made criminals for the loss of their unborn fetuses, even in such cases as being shot in the abdomen by another person ${ }^{1}$. South Korea's national birth rates have dropped to "record lows" for the "developed world." Anxieties over how the nation will maintain itself have spiked. Despite government incentive programs for parents, the birth rate continues to decline. Ecological concerns over climate change are often addressed with concern to future generations. Teenage climate activist Greta Thunberg, for example, stated in her speech at the United Nations Climate Action Summit on September 23rd of this year, "The eyes of all future generations are upon you. And if you choose to fail us, I say: We will never forgive you." Thunberg's ultimatum registers in cinematic expressions, as well. Cinema has long been used as a format to introduce political concepts. Films as varied as The Birth of a Nation (1915) to The Sound of Music (1965) were made with political messages at their forefront. The history of media is intrinsically bound up with the political history concurrent with their production: media both reflects upon and itself creates popular political attitudes of the time. I am particularly interested in the political messaging and impact on the general population that apocalyptic media has had in recent years, especially in 2020 as apocalyptic messaging increases

\footnotetext{
${ }^{1}$ Yan, Holly, and Madeline Holcombe. "A pregnant woman shot in the stomach is indicted in her unborn child's death." CNN
} 
during the COVID-19 crisis. The apocalypse is a deeply American fantasy, spurred on by the prevalence of evangelical sects such as the Millerites of the 19th century, who operated primarily within the Northeastern United States. Today, however, the apocalypse in media does not refer to its origins in Christianity, and has become instead a vessel to instill values of individualism and nationalism, despite how contradictory the two may seem at first blush, one being prioritization of the self and the other being the upholding of the national identity.

For this project, I will compare and contrast two dyads of apocalyptic filmed media with the goal of disclosing how filmed representations of apocalypse influence current expressions of nationalism, climate change, and reproductive and disability rights. First, I will directly examine the South Korean zombie-disaster film Train to Busan and compare it to the incredibly popular and long-running American television show The Walking Dead. Then I will examine the two recent apocalyptic invasion-disaster films A Quiet Place and Netflix's Bird Box. Each of these examples of apocalyptic media include representations of pregnancy, a surprisingly prevalent trope within apocalyptic media that scholarship has not yet adequately interrogated. I question the political messaging within each example, using the comparative method to highlight the differing political perspectives of each piece: Train to Busan, for example, promotes community support while criticizing capitalistic individualism. The two survivors at the end of the film are a child and a pregnant woman - both vulnerable members of society who only survive due to the protective actions of others, and are saved because they represent hope for a future human society. Meanwhile, The Walking Dead rejects community sacrifice, justifying any actions taken by the primary characters, including vengeance and even pre-emptive violent actions against other living people. The survival of the individual, and, extending out from that, the in-group of 
an individual family or village unit is the utmost concern, therefore any actions taken in that interest is justifiable. Here, too, pregnancy and children are key tropes. In The Walking Dead children protect as often as they are protected. They represent the future as owned and operated by Rick Grimes, the aggressive individualist at the center of the ten-years-running show.

My focus on Foucault's analytics of biopolitics serves to show how this ownership of reproductive bodies and of the product therein (infants/children) emphasizes a re-production of pre-apocalyptic values and norms. The apocalypse is imagined to be a necessary tragedy, forcing humankind to value what is important and abandon the trappings of advanced society, broadly imagined as post-enlightenment values such as caring for the elderly and/or disabled, where right are vested in all individuals regardless of ability or social rank. Apocalyptic media instead prioritize "valuable" individuals -- those who can produce work and value in the present, and those who can create value in the future (women and children). In the current global pandemic, we can see this eugenicist concept in practice as individuals with developmental disorders and the elderly are willingly sacrificed as their care and treatment for the ongoing COVID-19 pandemic is deprioritized ${ }^{2}$.

\section{Theoretical Framework}

I will use Lee Edelman's term "reproductive futurism" to discuss how the future is politically formulated to be something that can be owned by individuals in the present, as long as they control the means of (re)production. In this way, present-day owners of the future can attain a kind of immortality: though they themselves may die -- as they often do in these films -- they

\footnotetext{
${ }^{2}$ Amy Silverman. "People With Intellectual Disabilities May Be Denied Life Saving Care Under These Plans as Coronavirus Spreads" Arizona Daily Star.
} 
live on through the legacy of the child. Edelman's book No Future: Queer Theory and the Death Drive provides a useful framework for discussing the impact of reproductive futurism, though I largely disagree with the severity of his conclusions, such as his decrying of LGBT couples' choice to reproduce as assimilationist. I will also focus on Rebekah Sheldon's The Child Come to Life: Life After the Human Catastrophe to provide insight into the specific meaning of representations of children in apocalyptic scenarios. Her book will narrow my discussion in regards to the symbolism of the child in these films and television series, while Foucault will be my primary source regarding the overall theory of biopolitics and the (pregnant) woman's body as a capitalistic resource. I also have many more sources within the media analytics field discussing gender relations, sexuality, and the reproduction or subversion of norms through apocalyptic and/or zombie media. However, despite finding numerous sources on these subjects, no other discussion of reproductive futurism in apocalyptic media proposes the intersection of nationalism and current politics with a focus on the pregnant body. My specific film and television examples are simply too recent to have been discussed in academic publications as of yet. In this way, my thesis is poised to break new ground.

\section{Zombies, Pregnancy, and the Encoding of Apocalyptic Values}

Apocalyptic media exist to force a change and eliminate perceived flaws in existing society. This is done narratively through a force of nature, or via some outside influence which tragically and catastrophically destroys the majority of the population. While this is shown to be a traumatic experience for the characters who survive these events, it is ultimately seen as a necessary prequel to change. This change is morally blameless. There is no eugenicist leader 
culling the undesirables of the population, only mindless zombies or mysterious alien agents preying on the weak, the unprepared, the disabled. Those who are perceived as being too reliant upon community, or lacking in practical survival skills in favor of technological or social skills, or who are compassionate to those most vulnerable to the circumstances of the disaster are the first characters to die. There is no hopeful utopian future in this type of science fiction, only the hope for a future event so disastrous it enforces a sociological shift along primarily conservative lines that promotes individualism and returns society to hetero-patriarchal values and social systems.

My first media dyad compares and contrastsTrain to Busan and The Walking Dead. Target audiences between the two pieces of media vary greatly, the one a South Korean critique of capitalism and individualism; the other an American revelry in libertarian elevation of the self and reinforcement of white heteropatriarchal norms as key to survival. Both, however, are available to American audiences via the popular streaming service Netflix, and both present an apocalyptic scenario wherein the world is being overrun with undead monsters -- what will be hereafter referred to, somewhat inaccurately, as "zombies". The term "zombie" is of West African origin, grown from Haitian culture in reference to undead human creatures born, most commonly, from magic and spells. In modern Western usage, "zombie" has come to encompass an entire genre, with the "zombies" being created from such varied sources as a virus, radiation, parasitic infestation, or from no revealed cause whatsoever. When referring to "zombies" in the context of contemporary media, the "zombie" often need not even be undead but simply a mindless, violent human affected by some mysterious and infectious phenomenon who typically spreads the infection through contact with bodily fluids, such as a bite. Such is the case in both 
Train to Busan and The Walking Dead, though significant differences exist between the zombies of each work of fiction: in Train to Busan, humans turn into zombies within moments of being bitten, and the zombies themselves move quickly, with their only apparent weakness being poor sight. In The Walking Dead, zombies move slowly, their danger lying in numbers and relative invulnerability. It can take several hours for a person to turn into a zombie, something which only occurs after they succumb to the disease and perish.

This differentiation between types of zombies sets the stage for the political and moral messages of each piece of media. The zombies populating the post-apocalyptic world of The Walking Dead are, fundamentally, survivable phenomena: strategies of avoidance, physical strength and ability to fight, and ability to use existing infrastructure to barricade oneself away from the threat are demonstrated to be effective survival tactics in the world of The Walking Dead. These strategies are also, ironically, the strategies currently used to reduce exposure and spread of Coronavirus. By contrast, the zombies of Train to Busan are highly contagious, violent, and nearly impossible to escape. Survival is not a byproduct of successful strategy as much as a combination of cooperative action and luck.

In The Walking Dead, violence is enacted on the zombie hordes more often even than on the survivors, providing cathartic images of extreme gore and brutality inflicted on the imagined perpetrators of chaos - foreign elements divorced just enough from humanity as to make their bloody deaths supposedly exempt from ethical critique. The characters in Train to Busan, however, are never shown to successfully kill a zombie. While the zombies of the film often fall from great heights or drag along behind the commuter train on which the majority of the film is set, they are never shown to die from these circumstances. The only relief to be found is through 
escape. In fact, no character ever even attempts to kill a zombie: the only alternative is to beat them away from themselves or allow others to become zombies through selfish action in the effort of self-preservation. There is an implication, at the end of Train to Busan, that zombies can be killed, as soldiers are barricaded at the end of a tunnel, charged with shooting any figures coming through that can not be successfully identified as living humans. Despite this, no death of a zombie is shown on-screen. The zombie does not represent a foreign element that can be battled, but a kind of disaster on the scale of nuclear meltdown or fast-acting disease. What is important is not the prioritization of survival of the individual, but the effort to save as many as possible, disregarding the self.

Nowhere is the differentiation in political messaging between Train to Busan and The Walking Dead more clearly shown than in their respective representations of pregnant women and, for that matter, of children and of the men who provide protection for the former two groups. In Train to Busan, Syeong-Kyeong is a pregnant woman accompanied by her husband. She and the little girl, Soo-an, are the only surviving characters from the commuter train at the end of the film. Though Syeong-Kyeong and Soo-an are never violent or provide any clever plans to aid in survival, their worth is shown in their kindness and consideration for others: Syeong-Kyeong in her care and protectiveness towards Soo-an, and Soo-an in her selflessness towards an elderly woman on the train as she gives up her seat in favor of the old woman, even as the outbreak is already well underway. They are, in turn, cared for by others: Sang-Hwa, Syeong-Kyeong's husband, and Gong-Yoo, Soo-an's father and the main character of the film. Both men sacrifice themselves for the benefit of their family and each others' families, holding on long enough to ensure the safety of their loved ones, choosing to die rather than see those who 
cannot protect themselves die. At the moment before his death, Sang-Hwa names his unborn child, ensuring his legacy even as his life comes to an end. When Gong-Yoo becomes a zombie himself at the end of the film, he recalls the birth of his daughter Soo-an, giving up his life with a smile on his face.

Clearly, children and pregnant women (with the implied future of the unborn child) are prioritized within the film Train to Busan. They are not, however, the only lives viewed as worth saving within the context of the film. In fact, the deaths that do occur over the course of the film are often shown to be completely avoidable, had others been less self-serving and willing to sacrifice others. Yon-suk, the chief operating officer of a large company, represents self-interest, fear, and capitalistic individualism as he sacrifices others, going so far as to literally push other people into the paths of the zombies in order to ensure his own escape. Contrasted with Gong-Yoo's collaborative efforts, the audience can see that the deaths caused by Yon-suk's selfishness are unnecessary and preventable. In the end, Yon-suk cannot even prevent his own demise through this methodology, and instead causes one last preventable death in Gong-Yoo.

In Train to Busan, lack of ability is represented not only through the child and pregnant woman, but through a pair of elderly sisters as well. They, like the child and pregnant woman in the film, are vulnerable portions of the population, either protected or sacrificed by others. As revenge for the majority decision to sacrifice her sister, the surviving old woman opens the door between the zombie horde and the group which decided to let her and others die for their own self preservation, ensuring not only their deaths but her own as well. The selfishness of the group in neglecting to protect the vulnerable, rather than the vulnerability of those less-abled characters, is what is being critiqued in this film. Here, the future as represented in both the child 
and the pregnant woman, is actually aligned with the past and with disability as represented by the old woman. Able-bodied and capable adults are criticised for selfish responses which make no effort to protect at-risk populations.

The Walking Dead, on the other hand, idealizes individualism and self-interest; vulnerability of the individual leads to vulnerability of the group. Collaborative and communal efforts are seen as foolish and weak, representative of a world which could only exist during a time of peace and comfort. While a group is certainly needed for survival, said group has no room for 'weaklings' of any kind - old age, disability, or inability to 'contribute' through means of fighting or medical expertise prevent a person from having value for the group, instead becoming a burden and dragging the group down. Here, vulnerable populations are seen as an active burden on the able-bodied adult population. Characters such as Carol, an older abused woman portrayed as meek and useless, must evolve into cold-hearted fighters in order to be appreciated not only by the cast of characters within the story, but by the American audience as well. Lori's pregnancy throughout the first and second seasons of The Walking Dead brings serious concerns, not only in the form of decreasing Lori's 'usefulness' to the group, but also bringing to light certain political and moral concerns prevalent in America today: the threat of the destruction of the nuclear family through "liberal" ideals, such as reproductive rights for women.

During the first season of The Walking Dead, Lori is initially under the impression that her husband, series protagonist Rick Grimes, has been dead for several months. Within this implied context before the first episode, Lori and Rick's best friend, Shane, have begun a romantic relationship in Rick's absence. When Rick returns, he and Lori reconnect, creating a 
love triangle filled with animosity surrounding the supposed unfaithfulness of Lori. As a result, there is a question of paternity when Lori reveals her pregnancy. She initially wants to terminate the pregnancy by taking a handful of "morning-after" pills, collected at great risk to other characters who then despise Lori for apparently putting them in danger. Lori later vomits the pills, which seems to tell her that the pregnancy was 'supposed' to occur, in a semi-spiritual sense. Rick declares the pregnancy a gift and blessing, deciding to ignore the questionable paternity of the unborn fetus, believing the child must be his. The Walking Dead is presenting an unquestionably "pro-life" political viewpoint, decrying Lori's actions at every turn: that she dared to be 'disloyal' to the husband she believed to be dead, that she is somewhat unsure of how to proceed when Rick unexpectedly returns, and that she would even consider terminating her pregnancy, despite the apocalyptic scenario in which she finds herself. The fan response echoes these sentiments even more strongly, despising Lori for her doubts despite her continual acceptance of all that Rick demands of her. Even Lori's eventual death in labor, sacrificing herself in favor of her infant by asking for a makeshift $\mathrm{C}$-section is not enough to redeem her in the eyes of The Walking Dead's politically charged fanbase. As one fan stated online after the death of Lori's character: "Lori Grimes left The Walking Dead the same way she came in. With her pants off' (Blake). This comment is representative of the general popular response to Lori's character, which condemned her as unfaithful to heteropatriarchal norms and applauded at the event of her death in childbirth -- a distinctly gendered and self-sacrificial storyline meant to redeem Lori to the fans.

While The Walking Dead continues into 2020, marked with various character pregnancies over the years (most of which either fathered by Rick Grimes or otherwise taken under Rick's 
paternalistic governance/protection), Lori's pregnancy defines nearly the entirety of her characterization during her short span on the show and provides unique insight into the political messaging around pregnancy exhibited on The Walking Dead. Lori is critiqued harshly at every turn, both by the narrative structure and writing of the show itself, and by the fans of the show. Fan response of The Walking Dead has been extremely vocal, allowing us to peek inside the politics of the group most influenced by the political messaging of The Walking Dead, a show which has reached incredible heights of popularity in America, as evidenced not only by the existence of spin-off books, video games, and additional television shows, but also the large number of fan-operated websites. These include sites such as undeadwalking.com, thespoilingdeadfans.com, spoilthedead.com, and more. The official Facebook web page for The Walking Dead boasts a following of 33,117,391 people. This explosion of popularity places The Walking Dead squarely within the realm of social phenomenon during a global increase in nationalistic rhetoric and lawmaking.

\section{Children as Terrain: Futures of Bodies and Climate in Two Apocalyptic Films}

In the next dyadic comparison, I will discuss the two recent films Bird Box (2018) and A Quiet Place (2018). Themes which occur in both films include heteropatriarchal social structures, the endangered future of child/ren, mysterious foreign terrors, and representations of disability. As two apocalyptic films which debuted in the same year, Bird Box and A Quiet Place are shockingly similar in type and message.The first of these is a Netflix streaming service original film, whereas the second was a blockbuster hit. Both films feature pregnancy heavily, providing a wealth of political messaging within their respective representations. While Train to 
Busan and The Walking Dead are useful to compare due to their distinct contrast from one another, Bird Box and A Quiet Place are primarily useful to analyze the ways in which their similar political messages reflect upon a very specific moment and attitude in modern American politics.

Bird Box is a film which explores, theoretically, the relationship of the unwilling mother to her child. While Mallory, portrayed by Sandra Bullock, works throughout the film to protect her child/ren from physical harm, she simultaneously protects herself from potential vulnerability and pain by refusing an emotional connection to the children. She rejects these children as representations of a now-impossible future, one in which no children could grow to have meaningful life experiences or relationships with other human beings. This reflects on Lee Edelman's discussion of reproductive futurism, and Mallory's apparent rejection of said futurism. Before the apocalyptic scenario even begins, Mallory is stated to be "in denial" about her pregnancy - already in her third trimester. There is no indication that Mallory has ever considered abortion throughout her experience with pregnancy, though adoption is dicussed by her doctor. Mallory is not shown to either refuse or regard this option, as she chooses instead to ignore the impending deadline of birth. The apocalyptic scenario which unfolds involves a mysterious presence, invisible yet influential to the eye, which causes individuals to experience hallucinations and to subsequently commit suicide in whatever way is most convenient at the time. What follows is a continuous reiteration of individualism and self-preservation as the 'smart' choice under dangerous circumstances: whenever an individual character makes a choice to save others from danger, they perish as a result. The very first person to help Mallory aids her due to her visible pregnancy promptly succumbs to hallucination and calmly steps into a burning 
vehicle. Throughout the rest of the film, sacrifice and compassion are repeatedly portrayed as imprudent attempts at normalcy in the context of a disaster which demands self-centered focus on survival. The owner of the house in which Mallory seeks refuge, the grocery store clerk, and even the man characterized entirely as bitter and selfish are all killed while attempting to help others, an action framed within the narrative as heroic yet ultimately foolish. Bird Box introduces a character foil to Mallory through Olympia, another pregnant woman. Where Mallory is tough, independent, middle-aged and thin, Olympia is her opposite: self-described as soft and pampered, dependent on Mallory for emotional support, young, and overweight. Her compassion in allowing a stranger into the house ultimately results in the deaths of most of the remaining inhabitants, on the day in which both she and Mallory go into labor at the same time. Selflessness is equated with weakness, and Mallory is only able to keep the children alive for years through her toughness and self-preservation, allowing no emotional vulnerability -- even referring to her children as simply "boy" and "girl." Throughout the film, Mallory and the children have sought refuge advertised over radio. When they find it, it is revealed to be a pre-existing school for the blind, with a thriving community of survivors, including young children. Mallory meets up with a survivor she recognizes: her obstetrician-gynecologist from before the apocalyptic events began. This reunion, combined with the presence of other surviving children, reinforces the reproductive futurity present within the children today, whom Mallory finally names. Disregarding Olympia's previously mentioned name preferences, Mallory names her daughter "Olympia" and her own son "Tom" after Mallory's romantic interest who, once again, had died in a patriarchal sacrifice while protecting her and the children. 
The reproduction of the past into the future is prioritized, as opposed to emphasizing any individuality of the children as characters in their own right.

By contrast, A Quiet Place emphasizes family values not through a denial of emotional connectivity subsequently amended, but through the moralizing portrayal of a heteropatriarchal nuclear family. The film is set in a post-apocalyptic environment, centralized on a rural community and a single family within it. Like Bird Box, the primary threat in this scenario is a mysterious foreign - potentially extra-terrestrial - predatory monster. This monster hunts not through sight but sound, possessing not only incredible physical prowess such as speed and strength, but a finely tuned sense of hearing. As a result, the family - consisting of three children and a mother and father - must pad their bare footsteps with sand and use American Sign Language to communicate. This rural family stands at a distinct advantage in this particular apocalypse, due to the fact that the eldest child is herself deaf and the family already knew how to communicate with each other using ASL, as well as being situated on a farm and therefore capable of growing and storing their own produce. In the first scene of the film, the family has ventured out to the nearby town in order to raid the abandoned pharmacy for medication for the sick middle child, a boy. The youngest boy, who appears to be around five, is shown to be a constant threat to his own safety and the safety of his family through his naive fumbling with electronic toys. Though the father removes the batteries from the rocket toy, the boy lags behind the family and retrieves the batteries, later activating the toy and the electronic sound effects which accompany it, resulting in his death as he is quickly taken by one of the strange alien creatures. The story fast-forwards a little over a year, at which point the mother is already nearing the end of a pregnancy even as the family continues to quietly mourn the loss of the 
youngest child. The relationship between the father and the eldest child has grown strained, as the daughter blames herself and feels blamed by her father for the youngest child's death. Paternalism and heteropatriarchal values are demonstrated throughout the film as the daughter, despite being the oldest of the children, is made to stay at home with her mother, washing laundry and cooking food. Meanwhile, the younger boy, who is terrified of the world beyond the farm, is forced to accompany his father on a fishing trip and allowed to bond with his father. There is no explicit discussion of gender roles, yet those roles are made abundantly clear through exposition throughout the film. The mother's pregnancy in A Quiet Place reflects the heteropatriarchal values rife within the film, especially in its unquestioned nature as a continuation of the family unit. Though precautions must be taken in this apocalyptic environment, the family is still shown to play Monopoly (with felt pieces) and go about daily chores in a normal, if subdued, way. Therefore there is no question of whether to reproduce, just as for most white heterosexual and cisgender couples, there will never be a question of whether reproduction and parenthood is right for them. If it were not for the daughter's disability, this family would be the picture-perfect representation of heterosexual cisgendered white all-American familial ideal. That disability, however, provides a narrative structure and ultimately reveals the weakness of the alien monsters when proximity to the daughter's faulty hearing aid causes high-pitched feedback and weakens the aliens. In both Bird Box and A Quiet Place, physical disability is featured as the ultimate key to overcoming the threats presented to "normal" society. Typically, disability is targeted as weakness in apocalyptic scenarios; in these films, however, physical disability is shown to be not exactly a strength but an advantage. This advantage is used for the benefit of the able-bodied characters as these disabled characters form a 
narrative in which their 'weakness' becomes an exploitable value and capitalistic resource, much like the pregnant body or the body capable of pregnancy. These disabled bodies ensure the future for the abled present in a nearly-sacrificial way - after all, they have (narratively) given up their physical ability in order to foil a deadly threat to all.

Disability and nationalism connect through this ideal of sacrifice. Sacrifice of the American soldier is a familiar concept, as we continue to be mired in various wars in the Middle East. Today, sacrifice for the nation has become a concept more broadly applied to the American citizen: from essential workers to the disabled and elderly, sacrifice for national strength and economy is framed as a heroic choice made by individuals, rather than the result of policies in which citizens have little to no choice to sacrifice their lives for the survival of the local and national economies during the ongoing COVID-19 crisis. American nationalism has been increasing significantly since 2001, with the terrorist attack on the twin towers in New York on 9/11. Since then, individual freedoms have been continually sacrificed in favor of nebulous concepts of security and patriotism. Since approximately 2002, we have also seen an increase in apocalyptic media, providing citizens with an outlet for their fears: fear of unstoppable change, and fear of the absence of change. After all, post-apocalyptic media often shows audiences that the strong and worthy will survive, creating a new way of life which values the "right" things over shallow consumerism and laziness as perceived in society today. Apocalyptic media provides a specific subset of working class, typically white, straight, male individuals with an escapist fantasy in which their skills are suddenly valued above those of the corporate executives and software engineers. Within this fantasy lies a desire to rid themselves and the world of "undesirables" or of the "burdens" of the world, most particularly the disabled and the 
non-white. Women become vessels for reproduction, with little else to give them any merit in this idealized post-apocalyptic, pared-down society. Apocalyptia is infused with eugenics and white supremacy, hidden behind a veil of science-fiction and horror.

In all four pieces of media I have analyzed here, pregnant bodies as well as young children are featured as symbolic representations of re-produced, re-normalized post-apocalyptic futures which exist in the nebulous world of life-after-media. Presumably, surviving children go on to re-create norms of pre-apocalyptia, ensuring a return to "normalcy" and implying a continued reproductive capability of humankind as a race. Edelman's "reproductive futurism" refers to this process of imagining the future embodied within the existence of the child - a concept I push slightly further by emphasizing the reproductive (pregnant) body as not only symbolic of future generations, but of capital. In Foucault's Birth of Biopolitics, the body which is capable of labor is the creator of capital, with capital being defined as " that which makes a future income possible" (Foucault, 224). How much more so is the reproductive or pre-reproductive body - the body which either is or can become pregnant - a representation of limitless potential capital. Foucault describes this potential in these terms:

“... if you want a child whose human capital, understood simply in terms of innate and hereditary elements, is high, you can see that you will have to make an investment ... to have a social status such that it will enable you to take for a spouse or co-producer of this future human capital, someone who has significant human capital themselves" (Foucault, 228).

This theory of reproduction as a producing of future capital clearly ties into eugenicist theory. As often as the pregnant body is lauded for its potentiality and its capacity for production, disability 
is despised for its, by definition, lack-of-ability. When the body itself is figured as an "abilities-machine," any decrease in ability, whether in one function or many, is viewed as a negative drain on the community or society in which the disabled person(s) must exist.

As we are seeing currently during Donald Trump's ongoing response to the global coronavirus pandemic, disabled individuals are "expected" or "acceptable" losses under extraordinary circumstances, revealing that rights and consideration for the disabled are considered "luxuries" in progressive societies. As soon as a crisis occurs, these groups and individuals fall to the wayside: there is no room for "luxury" anymore. The same can be seen of reproductive rights, as outlined by Sheldon: “Women's control over their reproductive capacity, in other words, is a luxury that cannot be sustained in the state of emergency that attends the specter of extinction" (Sheldon, 56). This can be seen even in contemporary states, such as Israel and South Korea, which emphasize the importance of reproduction to bolster the strength of the nation. Once exaggerated to the point of apocalypse, it is easy to see how this hypothetical scenario is used to push political narratives of nationalism and individualist self-preservation. Even sacrifice of the literal self can be used to ensure one's personal legacy through the child or, more broadly, one's race or nationality.

Climate disaster is one crisis in which ideology of sacrifice begins to narrow its focus on the disabled. In a news article from September of 2019, climate disaster is discussed in relation to disabled populations in order to highlight the ways in which these groups are disregarded in the event of natural disaster. Power outages, flooding, and extreme heat are far more deadly factors for the disabled than the able-bodied, and there is a certain "assumption that some folks simply aren't cut out to survive" (Belser). Another article from November of 2019 similarly 
argues that disabled people, in current practice as well as theory, are expendable percentages of the population in the fight against climate change. Recent wholesale bans on plastic straws, power shut-offs in California as a response to high fire risks, and articles criticizing the use of inhalers as pollutants all work to both frame disabled people as burdens on society as well as to literally kill these individuals through irresponsible neglect of those who rely on things like electricity to operate oxygen tanks. Barbarin argues, "The disability community is living in a dystopian present where conserving the planet is in direct competition with the value of their lives.”

Pregnancy and reproductive rights have also seen a great deal of nationalist pressure recently. In an article published in November of 2019, Donald Trump's presidential mandate to activate a "global gag rule" to ban US funding of foreign NGOs which provide abortion counseling or referrals is shown to have had global repercussions. The word "abortion" has itself become taboo in areas like Nepal, which cannot afford to elicit the ire of the United States. Under Trump's expanded policy, even non-US funds are subject to the same moratorium on abortion referrals. This is not the only way in which US nationalism has resulted in worldwide changes in policy and attitude towards the pregnant-or-potentially pregnant body. A Hong Kong airline in January of 2020 insisted that a female passenger take a pregnancy test in order to prove she was not pregnant - a policy put into place to "help ensure that US immigration laws were not being undermined" (Scribner). Trump's nationalist policies against so-called "anchor babies" has had wide-reaching consequences, as once again the reproductive body is considered a tool of nationalism. In this case, it is a question of the in- versus the out-group, where "outsiders" and the potentiality of reproduction of the outsider is viewed as a threat to the insider and national 
identity. Fear is located within potential change - in this case, demographic change. Once again, this connects back to theories of apocalyptia, and the emphasis of in-group solidarity against threatening invaders - whether they be extra-terrestrial predators or post-human zombie hordes.

Once contextualized within the current COVID-19 crisis, these previously-existing ideals of sacrifice and reproductive futurism come into an even sharper clarity. Pregnancy during this global pandemic presents complications for both mother and infant, wherein several newborn infants have tested positive for the novel coronavirus (Milstone). Imagery of pregnant women in face masks abound throughout popular media, even in commercials -- one such commercial, for the social media site Facebook, draws comparisons between pregnancies during the Spanish Flu and COVID-19. Though the Spanish Flu began in 1918 and continued until the end of 1920, the precise one hundred year gap between 1920 and 2020 is emphasized in the commercial. This comparison, along with 'inspirational' music and photos of women in both the early 1900's and in 2020 immediately following birth (within the Facebook photo format) attempts to comfort the audience by providing assurance that this event is situated within a historical precedent. The commercial ends by telling the audience that "we" (mothers? Families? American society at large?) will get through this: after all, it has happened before. Fears surrounding the pandemic are acknowledged and addressed socially, rather than medically: Facebook can be a cure to the coronavirus. Anxieties regarding health and wellness are not addressed, only the loneliness of isolation as a new mother cut off from support systems.

Meanwhile, within the medical realm, the elderly and individuals with intellectual disabilities are actively being neglected for treatment, "saving" ventilators for the abled. Bérubé, a professor of literature at Pennsylvania State University and parent to a 28-year-old man with 
Down syndrome, stated "It would be a very rare person who sees a person with Down syndrome as innately as valuable and as able to contribute to society as anybody else" (Silverman). Dan Patrick, the lieutenant governor of Texas, has responded to the economic crisis lurking within the COVID-19 health crisis by declaring that seniors such as himself should risk death so that social distancing can end and the economic crisis averted. Though Patrick defends this claim by placing himself within the at-risk population, his status and wealth along with relative health give him better odds of survival than the average senior citizen he addresses. President Trump's statement that "the cure is worse than the disease" plainly situates the health of elderly and disabled populations as oppositional to the health of the state, wherein one cannot coexist with the other. State plans already exist which single out elderly and disabled patients as low-priority cases, such as Alabama's decision that those with "severe or profound intellectual disability" are unlikely to receive ventilator support, and Tennessee's declaration that those who need assistance with daily living are excluded from critical care (Ne'eman).

Nationalist tendencies have been on the rise in recent years; never more so than in the current COVID-19 crisis. As we have seen throughout this paper, reproductive futurism is intimately connected to and drives the forces not only of capitalism, but of nationalism and eugenics as well. The future is a plane constantly in flux, yet existent within the present: the future is, or "should" be, a reproduction of current values, changing only through increasing genetic superiority through subsequent generations. As Rebekah Sheldon states in The Child to Come, "Through the child, concerns over reproduction merge with and emerge through the social reproduction of norms" (Sheldon, 4). The theoretical imagining of apocalyptic scenarios serves as a thought experiment which asks how this derailed future can be put not only "back on track," 
but actually improved through the means of apocalypse and the culling of "burdens" on society. Weakness and vulnerability lead to death, which is seen as a tragic necessity at worst and the ideal process of societal and genetic evolution at best. Pregnancy, disability, nationalism, and eugenics come together in the sub-genre of apocalyptic and post-apocalyptic fiction; a sub-genre with enormous appeal to the disenfranchised blue-collar, white, cisheterosexual male. The uptick in examples of apocalyptic media, and the popularity of these media, correlates with an increase in nationalism and political conservatism, a political observation made all the more relevant as we confront a different kind of apocalypse during the global coronavirus pandemic -- one in which there are no zombies to fight or monsters to blame. 
Bibliography

A Quiet Place. Directed by John Krasinski, starring Emily Blunt and John Krasinksi, Paramount Pictures, 2018.

Balaji, Murali. Thinking Dead: What the Zombie Apocalypse Means. Lexington Books, 2016.

Barbarin, Imani. “Climate Darwinism Makes Disabled People Expendable.” Forbes. 2 Nov., 2019.

https://www.forbes.com/sites/imanibarbarin/2019/11/02/climate-darwinism-makes-disabl ed-people-expendable/\#288299d03d5a

Belser, Julia Watts. “Disabled People Cannot Be 'Expected Losses' in the Climate Crisis." Teen Vogue. 23 Sep., 2019.

https://www.teenvogue.com/story/disabled-people-vulnerable-climate-crisis

Bird Box. Directed by Susanne Bier, starring Sandra Bullock and Trevante Rhodes, Netflix, 2018.

Blake, Meredith. "Fans join in wife-bashing on 'Walking Dead,' other AMC series.” Los Angeles Times, Dec. 6, 2012.

https://www.latimes.com/entertainment/tv/la-xpm-2012-dec-06-la-et-st-amc-wives-walki ng-dead-mad-men-breaking-bad-20121206-story.html

Byrd, Finch. “A Radical Take on Zombie Apocalypse: Dominic Mitchell's In the Flesh.” Oregon Undergraduate Research Journal, Volume 10 Issue 1 Winter 2017. https://scholarsbank.uoregon.edu/xmlui/handle/1794/23468

Darabont, Frank and Angela Kang, creators. The Walking Dead. American Movie Classics, 2010-.

Edelman, Lee. No Future: Queer Theory and the Death Drive. Duke University Press, 2004.

Foucault, Michel. The Birth of Biopolitics. Translated by Graham Burchell, Palgrave Macmillan, 1979.

Hart, Kylo-Patrick R., and Annette M. Holba. Media and the Apocalypse. Lang, 2009.

Jha, Nishita and Bhrikuti Rai. “Trump's Anti-Abortion Policies Have Created A Nightmare For Women In Nepal.” Buzzfeed News. Kathmandu, Nepal, 2 Nov. 2019. https://www.buzzfeednews.com/article/nishitajha/trump-global-gag-rule-nepal 
Latimer, Heather. "Bio-Reproductive Futurism: Bare Life and the Pregnant Refugee in Alfonso Cuarón's Children of Men." Social Text, Duke University Press, 1 Sept. 2011, https://read.dukeupress.edu/social-text/article-abstract/29/3 (108)/51/33686

Lury, Karen. "The child in film and television: introduction." Screen, Volume 46, Issue 3, Autumn 2005, Pages 307-314, https://doi.org/10.1093/screen/46.3.307 https://academic.oup.com/screen/article-abstract/46/3/307/1626653

McGlotten, Shaka and Jones, Steve."Zombies and Sexuality: Essays on Desire and the Living Dead.” Science Fiction Film and Television, vol. 9 no. 1, 2016, p. 137-142.

Milstone, Aaron, M.D., M.H.S. "Coronavirus in Babies and Kids.” Johns Hopkins Medicine, updated 13 May, 2020, https://www.hopkinsmedicine.org/health/conditions-and-diseases/coronavirus/coronaviru s-in-babies-and-children

Ne'eman, Ari. “I Will Not Apologize For My Needs.” New York Times, 23 Mar., 2020, https://www.nytimes.com/2020/03/23/opinion/coronavirus-ventilators-triage-disability.ht $\underline{\mathrm{ml}}$

Sargent, Greg. "A viral plea to let grandparents sacrifice themselves captures a truth about Trump." The Washington Post, 24 Mar., 2020, https://www.washingtonpost.com/opinions/2020/03/24/viral-on-air-plea-captures-an-esse ntial-truth-about-trump/

Scribner, Herb. "This Hong Kong airline made a woman take a pregnancy test before flying to Saipan.” Deseret News. 3 Feb., 2020. https://www.deseret.com/u-s-world/2020/2/3/21067196/hong-kong-express-airline-us-pa

$\underline{\mathrm{c}}$ ific-saipan

Sheldon, Rebekah. The Child to Come: Life after the Human Catastrophe. Minneapolis: Minnesota UP, 2016.

Silverman, Amy. "People With Intellectual Disabilities May Be Denied Life Saving Care Under These Plans as Coronavirus Spreads.” Arizona Daily Star, March 27 2020. Propublica. https://www.propublica.org/article/people-with-intellectual-disabilities-may-be-denied-lif esaving-care-under-these-plans-as-coronavirus-spreads

Train to Busan. Written and directed by Yeon Sang-ho, Redpeter Film, 2016.

Trimble, Sarah. "Undead Ends: Contested Re-beginnings in Apocalyptic Film and Television." School of Graduate Studies, McMaster University. Sept 2012. https://macsphere.momaster.ca/handle/11375/12546 
Ziegler, J.R. "That is My Wife: Reproductive Futurism and Patriarchal Competition." In: Queering the Family in The Walking Dead. Palgrave Pivot, Cham. 2018. 